\title{
Review
}

\section{Oral rehabilitation of patients after maxillectomy. A systematic review ${ }^{\text {th }}$}

\author{
D.M. dos Santos, F.P. de Caxias, S.B. Bitencourt, K.H. Turcio, A.A. Pesqueira, M.C. Goiato* \\ Department of Dental Materials and Prosthodontics and Oral Oncology Center, São Paulo State University (Unesp), School of Dentistry, Araçatuba, São \\ Paulo, Brazil
}

Received 21 March 2017; accepted 5 March 2018

Available online 11 April 2018

\begin{abstract}
Patients who have maxillectomy can be rehabilitated with reconstructive surgery or obturator prostheses with or without osseointegratable implants. To identify studies on possible treatments in this group, we systematically searched the Scopus, Embase, PubMed/Medline, and Cochrane databases to collect data on patients' characteristics, radiotherapy, and results related to speech, swallowing, mastication or diet, chewing, aesthetics, and quality of life. Of the 1376 papers found, six were included, and one other was included after an additional search of references. A total of 252 patients were included, and of them, 86 had reconstructive surgery, 91 were treated with obturator prostheses, 39 had reconstructive surgery or obturator prostheses associated with implants, and 36 had reconstruction plus an obturator prosthesis. Data on radiotherapy were incomplete. There is a lack of consensus about the indication for rehabilitation, as the treatment must be based on the individual characteristics of each patient.

(C) 2018 The British Association of Oral and Maxillofacial Surgeons. Published by Elsevier Ltd. All rights reserved.
\end{abstract}

Keywords: Palatal obturators; Maxillofacial prosthesis; Reconstructive surgical procedures; Oral surgical procedures; Rehabilitation

\section{Introduction}

Maxillectomy can cause maxillary defects such as oronasal fistulas, loss of support of the cheek and lip, as well as aesthetic defects in the middle third of the face, and functional impairment of speech and swallowing. ${ }^{1-4}$ Treatment includes reconstructive surgery or rehabilitation with an obturator prosthesis, and both can be associated with osseointegratable implants.

Reconstruction with grafts of autogenous tissue seems to be the patients' treatment of choice,,$^{2,3-10}$ but this can be

\footnotetext{
Work presented at the 6th Congress of Faculty of Dentistry of Araçatuba, UNESP. Araçatuba, São Paulo-Brazil. May 12th - 14th, 2016.

* Corresponding author at: Department of Dental Materials and Prosthodontics and Oral Oncology Center, Araçatuba Dental School, São Paulo State University - UNESP, Araçatuba, São Paulo, Brazil.

E-mail address: goiato@foa.unesp.br (M.C. Goiato).
}

challenging ${ }^{11}$ when defects are large, or when operations are done in conjunction with other treatments such as radiotherapy. Another option is to use obturator prostheses. These are made from diverse components, the vertical extension of which is the most important part, as it contributes to the efficiency of oronasal separation, retention and stability of the prosthesis, and results in a better quality of speech. ${ }^{11}$

Because of the wide range of treatments available, our objectives were to identify studies that are relevant to the treatment of patients after maxillectomy, to establish which treatments give the best functional and aesthetic results, and to show how radiotherapy can influence the outcome.

\section{Methods}

This systematic review was based on the Preferred Reporting Items for Systematic Reviews and Meta-analyses 
Table 1

Search details.

\begin{tabular}{|c|c|}
\hline Terms & Search details \\
\hline Maxillectomy treatment AND surgical reconstruction & $\begin{array}{l}\text { (maxillectomy[All Fields] AND ("therapy"[Subheading] OR "therapy"[All } \\
\text { Fields] OR "treatment"[All Fields] OR "therapeutics"[MeSH Terms] OR } \\
\text { "therapeutics"[All Fields])) AND ("reconstructive surgical procedures"[MeSH } \\
\text { Terms] OR ("reconstructive"[All Fields] AND "surgical"[All Fields] AND } \\
\text { "procedures"[All Fields]) OR "reconstructive surgical procedures"[All Fields] } \\
\text { OR ("surgical"[All Fields] AND "reconstruction"[All Fields]) OR "surgical } \\
\text { reconstruction"[All Fields]) }\end{array}$ \\
\hline Maxillectomy treatment AND prosthodontic rehabilitation & $\begin{array}{l}\text { (maxillectomy[All Fields] AND ("therapy”[Subheading] OR “therapy”[All } \\
\text { Fields] OR "treatment”[All Fields] OR "therapeutics"[MeSH Terms] OR } \\
\text { "therapeutics"[All Fields])) AND (("prosthodontics"[MeSH Terms] OR } \\
\text { "prosthodontics"[All Fields] OR “prosthodontic"[All Fields]) AND } \\
\text { ("rehabilitation"[Subheading] OR "rehabilitation"[All Fields] OR } \\
\text { "rehabilitation"[MeSH Terms])) }\end{array}$ \\
\hline Maxillectomy AND obturator prosthesis & $\begin{array}{l}\text { maxillectomy[All Fields] AND (obturator[All Fields] AND ("prosthesis } \\
\text { implantation"[MeSH Terms] OR ("prosthesis"[All Fields] AND } \\
\text { "implantation"[All Fields]) OR “prosthesis implantation"[All Fields] OR } \\
\text { "prosthesis"[All Fields] OR "prostheses and implants"[MeSH Terms] OR } \\
\text { ("prostheses"[All Fields] AND “implants"[All Fields]) OR "prostheses and } \\
\text { implants"[All Fields])) }\end{array}$ \\
\hline
\end{tabular}

(PRISMA $)^{12}$ guidelines and used the methods recommended by the Cochrane Handbook for Systematic Reviews. ${ }^{13}$ It was registered in the International Prospective Register of Systematic Reviews (PROSPERO) as CRD42015025375.
Table 2

Components of the PICO (participants, intervention, comparison, and outcome) question.

$\mathrm{P}$ (participants) Patients with oral defects after maxillectomies I (intervention) Rehabilitation of patients

C (comparisons) Different treatments for rehabilitation

$\mathrm{O}$ (outcomes) Effects of oral rehabilitation after maxillectomy on speech, swallowing, mastication, and diet; aesthetics, quality of life, and influence of radiotherapy on the result of rehabilitation

\section{Search strategy}

The search was conducted by two independent examiners (FPC and SBB), and in case of conflicts, the resolution was mediated by a third examiner (DMS) who was also the study advisor. We searched the PubMed/MEDLINE, Embase, Scopus, and Cochrane Library databases using the terms shown in Table 1, and excluded duplicated papers. After reading the titles and abstracts, we selected studies and read the full text. Those included were related to the rehabilitation of patients after maxillectomy whose defects were characterised only by oroantral communications. All studies published up to March 2017 were included.

We also searched for references encompassing all online issues of Head \& Neck; the International Journal of Oral and Maxillofacial Surgery; Journal of Oral Rehabilitation; Journal of Prosthetic Dentistry; Plastic \& Reconstructive Surgery; Journal of Oral and Maxillofacial Surgery; Oral Surgery, Oral Medicine, Oral Pathology and Oral Radiology; Journal of Cranio-Maxillo- Facial Surgery; Journal of Prosthodontic Research; and the British Journal of Oral and Maxillofacial Surgery, in which we found one article ${ }^{14}$ that fulfilled the inclusion criteria. Table 2 shows the components of the PICO question (participants, intervention, comparisons, and outcomes). The principal question to be answered was: "Is there an optimal choice for rehabilitation of patients after maxillectomy?".

\section{Inclusion and exclusion criteria and study selection}

Randomised clinical trials, and longitudinal and transversal studies, all in the English language, which reported the outcomes of reconstruction and use of obturator prostheses, were included. They reported patients with unilateral or bilateral maxillary defects, independent of the amount of resection. However, they could not involve the orbital floor or the eye socket, or both, since these would generate oroantral communications (Aramany classes I to VI, ${ }^{15}$ Cordeiro classes II and III, ${ }^{16}$ Brown classes I and II $^{17}$ and their horizontal variations ("a", "b", and "c"), and all Okay classes, ${ }^{18}$ except variation "f", as this involves the inferior rim of the eye socket) (Table 3).

Studies of patients with congenital defects or those caused by trauma or non-neoplastic diseases, reviews, systematic reviews, and case reports, were excluded. Papers had to contain both surgical and prosthetic treatments with or without osseointegratable implants, and results had to include at least one of the following: complications, functional results, aesthetics, quality of life, and efficacy of treatment. 
Table 3

Maxillectomy classifications.

Class Aramany ${ }^{15}$

Cordeiro $^{16}$

Resection is along the midline of the maxilla, the teeth are maintained on one side of the arch. This is the most

common maxillary defect, and most patients fall into this category

Unilateral defect, retaining anterior teeth on the contralateral side. Recommended design is similar to that of a Class II Kennedy removable partial denture, in which indirect retention minimises the possibility of being dislodged under gravity. This approach is favoured more than the classic maxillectomy described in texts on head and neck surgery.

Presurgical consultation with surgeons has modified their approach with the aim of preserving the dentition on the contralateral side. The central incisor and sometimes all the anterior teeth to the canine or premolar are saved

III Palatal defect is in the central portion of the hard palate and may involve part of the soft palate. The operation does not involve the remaining teeth. The design for these patients is simple, and retention, stabilisation, and reciprocation can be planned effectively

IV Defect crosses the midline and involves both sides of the maxilla. The few remaining teeth lie in a straight line, which may create a design problem similar to the unilateral design of conventional removable partial dentures
Limited maxillectomy includes resection of one or two walls of the maxilla, excluding the palate

Subtotal maxillectomy includes resection Low maxillectomy. Includes alveolus of the maxillary arch, palate, anterior and and antral walls but not the orbital floor lateral walls (lower five walls), with or rim preservation of the orbital floor

Total maxillectomy includes resection of all six walls of the maxilla

IIIa: total maxillectomy with sparing of orbital contents

IIIb: total maxillectomy with orbital exenteration

Defects (orbitomaxillectomy) include resection of the orbital contents and the upper five walls of the maxilla, with preservation of the palate the anterior base of the skull

Brown $^{17}$

Maxillectomy with no oroantral fistula Removal of alveolar bone does not result in an oronasal or oroantral fistula.

Resections of defects in the ethmoidal and frontal sinus cavity, or removal of the lateral nasal wall would fit into this category. It includes the removal of palatal bone only, which inevitably results in an oronasal fistula, but leaves the tooth-bearing part of the maxilla intact

Okay $^{18}$

Defects that involve the hard palate but not the tooth-bearing alveolus categorised as Class Ia

Defects that involve any portion of the maxillary alveolus and dentition posterior to the canines, or which involved the premaxilla are categorised as Class Ib. They involve a small portion of the dental arch; the anterior sextant and a unilateral posterior quadrant of teeth remain intact

Defects that involve any portion of the tooth-bearing maxillary alveolus, but include only one canine, are categorised as Class II. The anterior margin of these defects is within the premaxilla. This class also includes anterior transverse palatectomy defects that involve less than one half of the palatal surface

High maxillectomy includes the orbital floor with or without periorbita and with or without resection of the base of the skull

Radical maxillectomy plus orbital exenteration with or without resection of
Defects that involve any portion of the tooth-bearing maxillary alveolus and include both canines, total palatectomy defects, and anterior transverse

palatectomy that involve more than half of the palatal surface, are categorised as Class III. They leave little or no residual palate or dentition for the secure retention of an obturator, which leads to a poor prosthetic prognosis 
It is rare to have an acquired maxillary

defect anterior to the remaining abutment

teeth. It occurs mostly in trauma or in

congenital defects rather than as a

planned operation. Cross-arch

stabilisation is achieved through a

system of cross-arch bars, which will

provide wide distribution of support and

retention from separated abutment teeth

$-$

$-$
Resection of unilateral alveolar maxilla and hard palate. Less than or equal to resection of half the alveolus and hard palate, and does not cross the midline or involve the nasal septum

Resection of bilateral alveolar maxilla and hard palate. Includes smaller resection that crosses the midline of the alveolar bone, including the nasal septum Removal of entire alveolar maxilla and hard palate
Defects that involve the inferior orbital rim

Defects that involve the body of the zygoma 


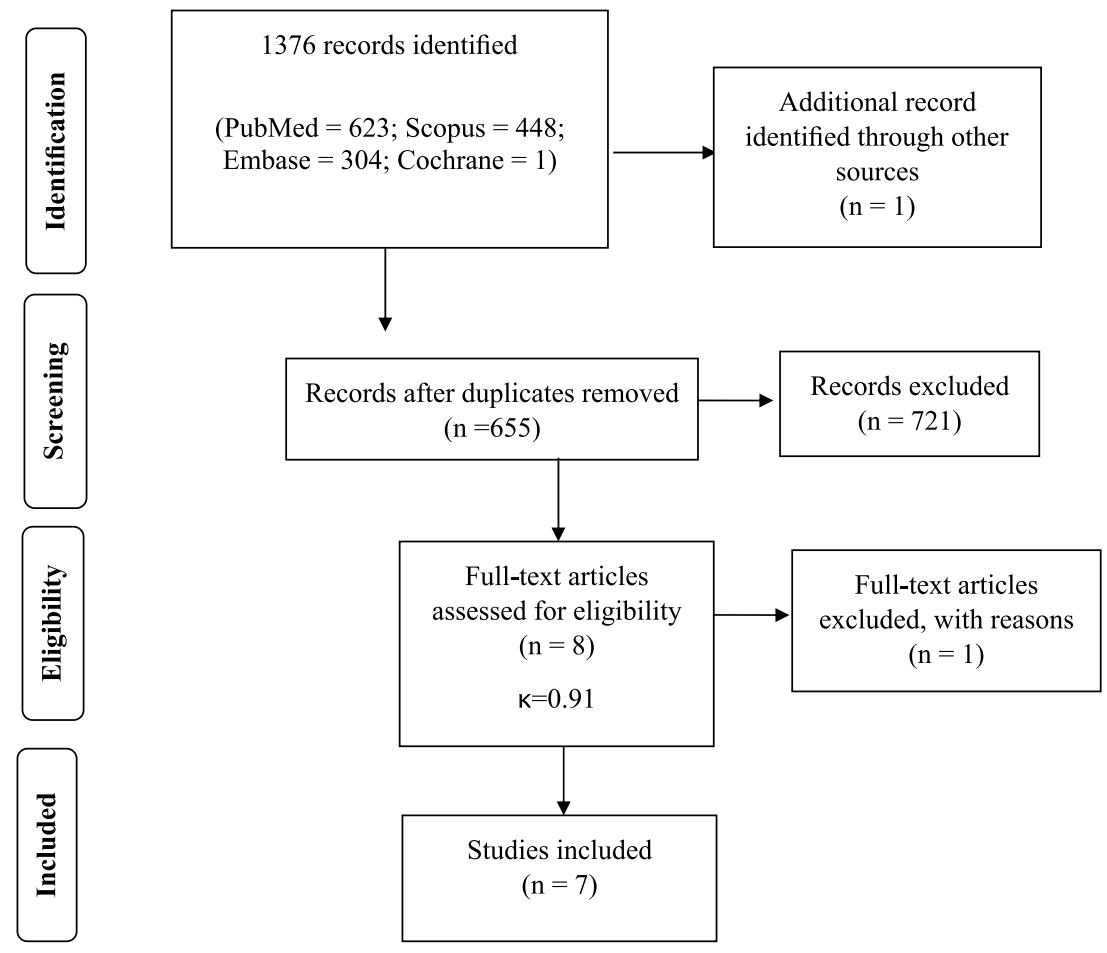

Fig. 1. Flow chart of systematic search and review process.

\section{Evaluation of agreement and level of evidence}

We used a weighted Cohen's kappa ${ }^{19}$ test to evaluate the level of agreement between the examiners at two points: the first, shortly after the titles and abstracts had been read, and the second after the final selection had been made. The level of evidence of the studies included was based on National Health and Medical Research Council guidelines. ${ }^{20}$ This classification system assigns levels of evidence (I, II, III-1, III-2, III-3, IV) according to the type of research, and assists in the classification of clinical studies with varying levels of evidence. ${ }^{20}$

\section{Collection of data}

We tabulated the data on a spreadsheet that contained the details of the patients, classification of the defects, postoperative results and complications, functional results, aesthetics, quality of life, and efficacy of treatment. We also collected data on the accompanying treatment of neoplasia with radiotherapy.

\section{Results}

Fig. 1 shows the selection of studies. We read the complete text of seven, excluded one ${ }^{21}$ because the data were incomplete, and found one other ${ }^{14}$ after an additional search of the references in all online issues. Five studies were retrospective, ${ }^{7,9,10,22,23}$ one was prospective, ${ }^{14}$ and one was a retrospective cohort study. ${ }^{8}$ The level of evidence was III-3 for the prospective and retrospective studies, and III- 2 for the retrospective review and cohort study. ${ }^{20}$

\section{Qualitative analysis}

Table 3 shows the classification of maxillary defects.

Of the 252 patients, 86 had reconstruction, 91 were treated with an obturator prosthesis, 39 had reconstruction or obturator prostheses associated with osseointegratable implants, and 36 had reconstruction and an obturator prosthesis. The mean ages ranged from 42.7 to 64 years, and patients had a maxillectomy for malignant or benign tumours. One study did not give the reason for the resections. ${ }^{22}$

Defects were reconstructed with rectus abdominis and latissimus dorsi myocutaneous flaps, temporalis flaps, iliac crest and fibular osteomuscular flaps, fibular osteomyocutaneous flaps, calvarial bone grafts, radial forearm fasciocutaneous free flaps; as well as anterolateral thigh, lateral arm, serratus composite, free rectus, iliac, and fibular free flaps. The classifications of the defects and their respective treatments are shown in Table 4.

\section{Radiotherapy}

Five studies $7,9,10,14,23$ included patients who had had radiotherapy, and one of them ${ }^{10}$ reported the presence of fistulas in some (Table 5). All but one of these studies ${ }^{14}$ reported satisfactory results for speech, aesthetics, swallowing, chewing, and quality of life, independent of the approach used 
Table 4

Details of the studies.

\begin{tabular}{|c|c|c|c|c|c|c|}
\hline $\begin{array}{l}\text { First author, year, and } \\
\text { reference }\end{array}$ & $\begin{array}{l}\text { Type of study and level of } \\
\text { evidence }\end{array}$ & $\begin{array}{l}\text { Mean (range) age } \\
\text { (years) }\end{array}$ & $\begin{array}{l}\text { No. of patients } \\
\text { and sex }\end{array}$ & $\begin{array}{l}\text { Indication for } \\
\text { maxillectomy }\end{array}$ & Type of maxillectomy & Treatment \\
\hline Bernhart $2003^{7}$ & $\begin{array}{l}\text { Retrospective analysis } \\
\text { III-3 }\end{array}$ & $49(7-83)$ & $\begin{array}{l}57 \\
\text { M:42 } \\
F: 15\end{array}$ & Malignant tumour & $\begin{array}{l}\text { Classification by the authors: } \\
\text { total maxillectomy, } \\
\text { premaxilla resection, } \\
\text { palatectomy, total bilateral } \\
\text { maxillectomy, and total } \\
\text { maxillectomy including } \\
\text { contralateral premaxilla }\end{array}$ & $\begin{array}{l}\text { Reconstructive surgery } \\
(\mathrm{n}=31) \text { Reconstructive } \\
\text { surgery with obturator } \\
\text { prosthesis }(\mathrm{n}=26)\end{array}$ \\
\hline Breeze $2016^{14}$ & $\begin{array}{l}\text { Prospective study } \\
\text { III-3 }\end{array}$ & $64 \mathrm{NR}$ & $\begin{array}{l}27 \\
\text { M:NR } \\
\text { F:NR }\end{array}$ & Malignant tumour & Brown classes I and II & $\begin{array}{l}\text { Reconstructive surgery (TF, } \\
\text { RF, AT) }(n=14) \text { Obturator } \\
\text { prosthesis }(n=13)\end{array}$ \\
\hline Costa $2015^{8}$ & Retrospective cohort review & $50.4(24-81)$ & $\begin{array}{l}\mathrm{M}: 8 \\
\mathrm{~F}: 14\end{array}$ & Malignant tumour & $\begin{array}{l}\text { Classification by authors: } \\
\text { Class I (limited } \\
\text { maxillectomy), Class II } \\
\text { (subtotal or infrastructural } \\
\text { maxillectomy) }\end{array}$ & $\begin{array}{l}\text { Reconstructive surgery } \\
(\text { McRA, McLD, OmIC, OmF, } \\
\text { OmcF), calvary bone graft } \\
(\mathrm{n}=15) \\
\text { Reconstructive surgery and } \\
\text { dental implant }(\mathrm{n}=1) \\
\text { Obturator prosthesis }(\mathrm{n}=6)\end{array}$ \\
\hline Elsherbiny $2008^{9}$ & $\begin{array}{l}\text { Retrospective review } \\
\text { III-3 }\end{array}$ & $42.7(41-55)$ & $\begin{array}{l}10 \\
M: 7 \\
F: 3\end{array}$ & Malignant tumour & Subtotal maxillectomy & $\begin{array}{l}\text { Reconstructive surgery (RF) } \\
\text { and obturator prosthesis } \\
(\mathrm{n}=10)\end{array}$ \\
\hline \multirow[t]{2}{*}{ Moreno $2009^{10}$} & Retrospective analysis & $54(9-88)$ & 59 & $\begin{array}{l}\text { Malignant and benign } \\
\text { tumours }\end{array}$ & $\begin{array}{l}\text { Brown Class II, Okay classes } \\
\text { Ia, Ib, II, and III }\end{array}$ & $\begin{array}{l}\text { Reconstructive surgery (AT, } \\
\text { OmcF, McRA, RF, LA, SC, } \\
\text { FR) }(\mathrm{n}=10)\end{array}$ \\
\hline & III-3 & & $\begin{array}{l}\text { M:NR } \\
\text { F:NR }\end{array}$ & & & Obturator prosthesis $(\mathrm{n}=49)$ \\
\hline Rieger $2011^{22}$ & $\begin{array}{l}\text { Retrospective analysis } \\
\text { III-3 }\end{array}$ & $52(21-79)$ & $\begin{array}{l}39 \\
\text { M:20 } \\
\text { F:19 }\end{array}$ & NR & Okay classes Ib and II & $\begin{array}{l}\text { Reconstructive surgery (FFF) } \\
(\mathrm{n}=16) \text { Obturator prosthesis } \\
(\mathrm{n}=23)\end{array}$ \\
\hline Wang $2016^{23}$ & $\begin{array}{l}\text { Retrospective analysis } \\
\text { III-3 }\end{array}$ & $50.9 \mathrm{NR}$ & $\begin{array}{l}38 \\
\text { M:23 } \\
F: 15\end{array}$ & $\begin{array}{l}\text { Malignant and benign } \\
\text { tumours }\end{array}$ & Okay classes Ib, II, and III & $\begin{array}{l}\text { Reconstructive surgery (FFF; } \\
\text { IFF) + implant-supported } \\
\text { fixed prosthesis }(n=20) \\
\text { Implant-supported obturator } \\
\text { prosthesis }(n=18)\end{array}$ \\
\hline
\end{tabular}

NR: not reported; TF: temporalis flap; RF: radial forearm fasciocutaneous free flap; AT: anterolateral thigh; McRA: myocutaneous rectus abdominis; McLD: myocutaneous latissimus dorsi; OmIC: osteomuscular iliac crest; OmF: osteomuscular fibula; OmcF: osteomyocutaneous fibula; LA: lateral arm; SC: serratus composite; FR: free rectus; FFF: fibular free flap; IFF: iliac free flap. 
Table 5

Studies that reported radiotherapy associated with maxillectomy, and complications related to radiotherapy.

\begin{tabular}{|c|c|c|c|}
\hline $\begin{array}{l}\text { First author, year, and } \\
\text { reference }\end{array}$ & Treatment & Follow up & Complications \\
\hline Bernhart $2003^{7}$ & $\begin{array}{l}\text { Reconstruction }(n=31) \\
\text { Reconstruction }+ \text { obturator prosthesis }(n=26)\end{array}$ & 37.5 months & NR \\
\hline Elsherbiny $2008^{9}$ & Reconstruction + obturator prosthesis $(n=10)$ & 25 months & NR \\
\hline Breeze $2016^{14}$ & $\begin{array}{l}\text { Reconstruction }(n=14) \\
\text { Obturator prosthesis }(n=13)\end{array}$ & $\begin{array}{l}\text { Mean (SD) } 14(4) \\
\text { months }\end{array}$ & NR \\
\hline Moreno $2009^{10}$ & $\begin{array}{l}\text { Reconstruction }(n=10) \\
\text { Obturator prosthesis }(n=49)\end{array}$ & At least 6 months & $\begin{array}{l}6 \text { of } 8 \text { patients who } \\
\text { developed nasocutaneous } \\
\text { fistulas had had radiotherapy }\end{array}$ \\
\hline Wang $2016^{23}$ & $\begin{array}{l}\text { Obturator prosthesis +implants }(\mathrm{n}=18) \\
\text { Reconstruction }+ \text { implants }(\mathrm{n}=20)\end{array}$ & NR & NR \\
\hline
\end{tabular}

NR: not reported.

(Table 6). Patients who had grafts of autogenous tissue had more complications including partial or total loss of the graft, oronatral fistulas, and necrosis (Table 6).

\section{Discussion}

The studies did not present a clear methodology or were not randomised or prepared as double-blind trials (levels of evidence: III- 2 or III- $3^{20}$ ).

Many classifications of the defects that result from maxillectomy have been described, ${ }^{15-18}$ and a variety of operations are done to treat a wide range of neoplastic processes that involve diverse anatomical locations. ${ }^{23}$ Although adjectives such as "limited", "partial", "medial", "subtotal", "total", "radical", and "extended" are normally added to define the extent of the operation, ${ }^{24-27}$ the lack of a standard nomenclature can be confusing. As authors used established classifications, or had devised their own, ${ }^{7,8}$ we did not consider the names of the classes used, but only the descriptions of each one. We designed Table 3 to show the classifications and descriptions of the principal authors clearly, and to identify the descriptions that met our inclusion criteria.

Primary closure of defects results in the best outcome and the least morbidity, but as this is not always possible, a graft may be necessary to close the wound, or an obturator prosthesis used. $^{7-10,28}$ The choice of approach depends on the extent of the defect and its location, the number of remaining teeth, and the quality and quantity of supporting tissue. ${ }^{17,18}$ Reconstruction is the patients' treatment of choice, and could be associated with the greatest satisfaction.

Grafts such as the radial forearm flap ${ }^{17}$ and the fibular free flap ${ }^{22}$ are indicated for small defects, and vascularised cranial bone grafts with remnants of the temporal region or galeopericranial flaps can also be used. ${ }^{8}$ Ideally, whatever the extent of the defect, the reconstruction must be done after the initial wound has healed. ${ }^{29}$ Sometimes it is necessary to replace the dentition lost during maxillectomy, as reported by Costa et $\mathrm{al}^{8}$ and in this case the relation of the prosthesis to the implant is crucial to maintain the position of the prosthesis.
Reconstruction with autogenous grafts, however, is not always the option of choice. ${ }^{30}$ Surgeons may choose not to close the defect (particularly in patients with malignant tumours) to accommodate probable relapses, and dehiscence of the grafted tissue can result in the development of a fistula, ${ }^{9}$ necrosis, ${ }^{8}$ or even a partial ${ }^{7,10}$ or total loss ${ }^{10}$ of the graft in those treated with radiotherapy. ${ }^{10}$ In these cases obturator prostheses are a viable option.

An obturator prosthesis can be planned for temporary or definitive treatment, ${ }^{7,31}$ or in conjunction with other operations, ${ }^{7}$ and can aid healing ${ }^{9}$ and help to eliminate problems related to speech and swallowing. ${ }^{7}$ Patients with large defects have fewer teeth, less tissue to support the prosthesis, and a larger area that requires support. ${ }^{18}$ In these cases, rehabilitation with an obturator prosthesis could be difficult because its vertical extension has to be large enough to cover the entire defect making it heavy, uncomfortable, and difficult to adapt to. ${ }^{28}$ To minimise this problem, a retained implant obturator prosthesis could be indicated, as long as the quality and quantity of bone is adequate for fixation of the implants. ${ }^{17}$ Only one study ${ }^{23}$ reported this method, and further investigation is needed.

Five studies ${ }^{7,9,10,14,23}$ reported the use of radiotherapy as an adjuvant treatment. Elsherbiny et $\mathrm{al}^{9}$ did not report complications, but Moreno et $\mathrm{al}^{10}$ reported that of the eight patients who developed nasocutaneous fistulas, six had had radiotherapy, which may have led to cellular necrosis or a reduced blood supply that complicated healing. ${ }^{32}$ Other authors $4,10,33$ also stated that outcomes in patients treated with radiotherapy seemed less favourable.

Maxillary resections can change the appearance and cause difficulties with speech and swallowing, ${ }^{7-9,22}$ which can profoundly affect a patient's quality of life. ${ }^{26,34}$ Speech, chewing, swallowing, aesthetics, and quality of life were the factors most commonly discussed. ${ }^{7-10,22}$ With the exception of Bernhart et $\mathrm{al}^{7}$ who thoroughly described their results, the other authors did not separate the results of different groups, which made analysis impossible. Although satisfactory results were reported for all treatments, these cannot be confirmed because they were all evaluated using different techniques. 
Table 6

Measurements of speech, swallowing, mastication/diet, aesthetics, quality of life (QoL), and postoperative complications.

\begin{tabular}{|c|c|c|c|c|c|c|c|c|}
\hline \multirow{2}{*}{$\begin{array}{l}\text { First author, year, } \\
\text { and reference }\end{array}$} & \multirow[t]{2}{*}{ Treatment } & \multicolumn{5}{|l|}{ Measurements } & \multirow[t]{2}{*}{ Complications/final outcomes } & \multirow[t]{2}{*}{ Follow up } \\
\hline & & Speech & Swallowing & Mastication/diet & Aesthetics & QoL & & \\
\hline \multirow[t]{11}{*}{ Bernhart $2003^{7}$} & $\begin{array}{l}\text { Reconstruction } \\
(\mathrm{n}=31)\end{array}$ & Reconstruction: & NR & Reconstruction: & Reconstruction: & NR & $\begin{array}{l}\text { Partial loss of free flap. } \\
\text { Obturator caused difficulty } \\
\text { chewing solids, and lacked } \\
\text { retention and also resulted in } \\
\text { hypernasal speech, but most } \\
\text { patients had satisfactory } \\
\text { results. }\end{array}$ & Mean 37.5 months \\
\hline & $\begin{array}{l}\text { Reconstruction } \\
+ \text { obturator } \\
\text { prosthesis }(n=26)\end{array}$ & Normal (8) & & Full diet (12) & Normal (5) & & $\begin{array}{l}\text { Final outcome: prosthetic } \\
\text { rehabilitation is better when it } \\
\text { follows reconstruction }\end{array}$ & \\
\hline & & Limited (0) & & Soft diet (9) & Limited (0) & & & \\
\hline & & Poor (1) & & $\begin{array}{l}\text { PEG/pureed diet } \\
\text { (3) }\end{array}$ & Poor (2) & & & \\
\hline & & NR (22) & & NR (7) & NR (24) & & & \\
\hline & & Reconstruction & & Reconstruction & Reconstruction & & & \\
\hline & & + obturator & & + obturator & +obturator & & & \\
\hline & & prosthesis: & & prosthesis: & prosthesis: & & & \\
\hline & & Normal (25) & & Normal (20) & Normal (21) & & & \\
\hline & & Hypernasal (1) & & Limited (0) & Limited (1) & & & \\
\hline & & Hyponasal (0) & & Poor (6) & Poor (4) & & & \\
\hline Breeze $2016^{14}$ & $\begin{array}{l}\text { Reconstruction } \\
(\mathrm{n}=14) ; \\
\text { Obturator } \\
\text { prosthesis }(\mathrm{n}=13)\end{array}$ & $\begin{array}{l}\text { Worse after } \\
\text { treatment }\end{array}$ & $\begin{array}{l}\text { Worse after } \\
\text { treatment }\end{array}$ & $\begin{array}{l}\text { Worse after } \\
\text { treatment }\end{array}$ & $\begin{array}{l}\text { Worse after } \\
\text { treatment }\end{array}$ & $\begin{array}{l}\text { No significant } \\
\text { difference after } \\
\text { treatment between } \\
\text { flaps and } \\
\text { obturators }\end{array}$ & NR & $\begin{array}{l}\text { Mean (SD) } 14(4) \\
\text { months }\end{array}$ \\
\hline \multirow[t]{2}{*}{ *Costa $2015^{8}$} & $\begin{array}{l}\text { Reconstruction } \\
(\mathrm{n}=15) \\
\text { Reconstruction+ } \\
\text { dental implants } \\
(\mathrm{n}=1)\end{array}$ & $\begin{array}{l}\text { All groups normal } \\
\text { (35) }\end{array}$ & NR & Soft diet (18) & Patients' score: & $\mathrm{NR}$ & $\begin{array}{l}\text { Total necrosis of flap. No } \\
\text { problem with obturator or } \\
\text { dental implants. }\end{array}$ & 24 years' review \\
\hline & $\begin{array}{l}\text { Obturator } \\
\text { prosthesis }(n=6)\end{array}$ & & & $\begin{array}{l}\text { Unrestricted diet } \\
(35)^{*}\end{array}$ & $\begin{array}{l}7.61 \text { (range } 5 \\
-10) ; \text { Surgeon's } \\
\text { score } 7.71 \text { (range } 4 \\
-10) *\end{array}$ & & $\begin{array}{l}\text { Final outcome: flaps are } \\
\text { preferable for large defects }\end{array}$ & \\
\hline Elsherbiny $2008^{9}$ & $\begin{array}{l}\text { Reconstruction } \\
+ \text { obturator } \\
\text { prosthesis }(n=10)\end{array}$ & $\begin{array}{l}\text { All patients as } \\
\text { good as before } \\
\text { operation }\end{array}$ & $\begin{array}{l}\text { All patients as } \\
\text { good as before } \\
\text { operation }\end{array}$ & NR & $\begin{array}{l}\text { All patients as } \\
\text { good as before } \\
\text { operation }\end{array}$ & $\begin{array}{l}\text { All patients as } \\
\text { good as before } \\
\text { operation }\end{array}$ & $\begin{array}{l}\text { Small oronasal fistula, but all } \\
\text { flaps successful. Oronasal } \\
\text { fistula. One patient died of } \\
\text { progression of local disease } \\
\text { Final outcome: immediate } \\
\text { reconstruction with flaps and } \\
\text { later with dental obturator is } \\
\text { reliable. Patients had no } \\
\text { problem related to functional } \\
\text { outcomes when obturator } \\
\text { removed }\end{array}$ & 25 months \\
\hline
\end{tabular}




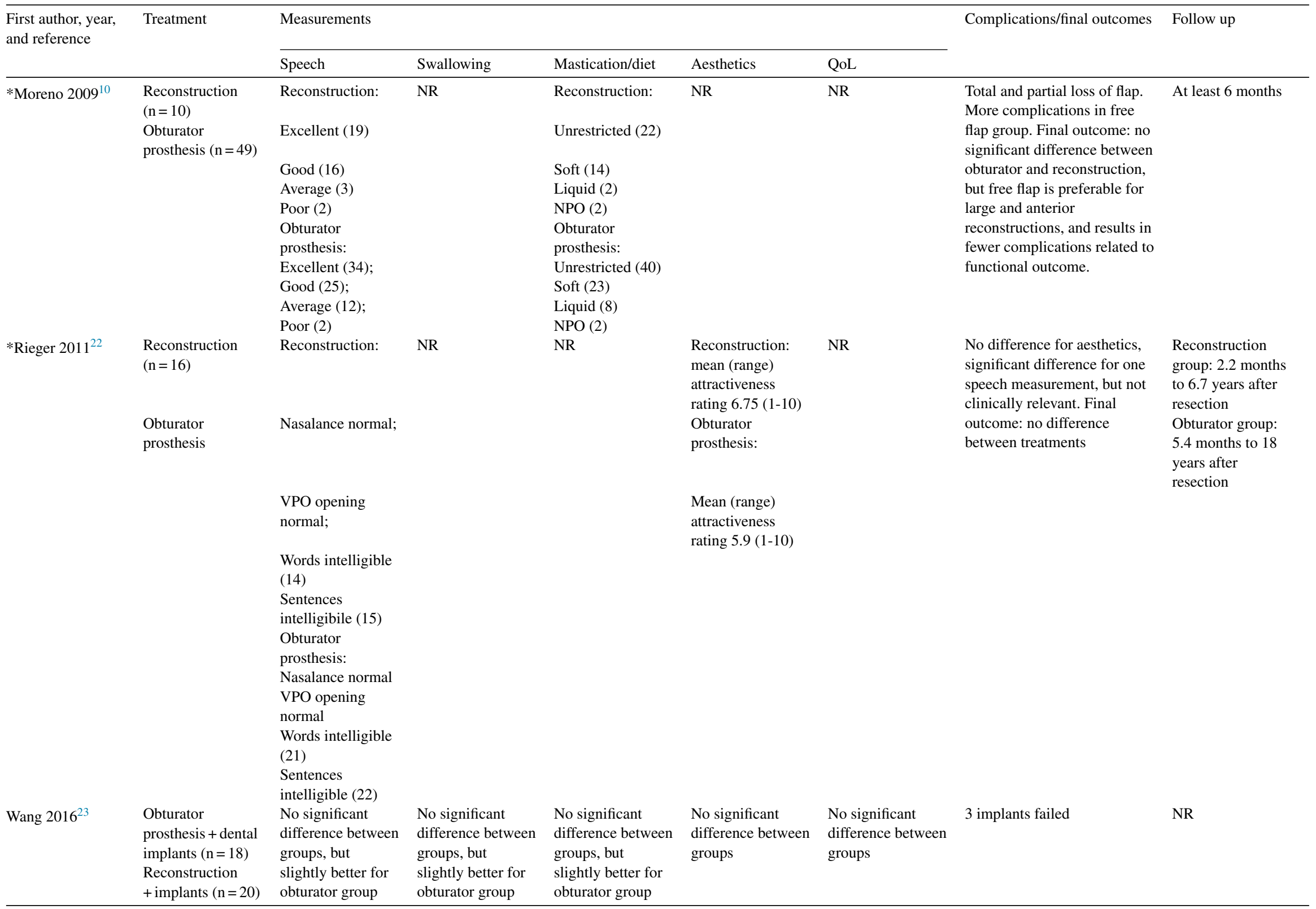

PEG: gastrostomy tube feeding (+) positive results; NR: not reported; NPO: nothing prescribed orally; $(*)$ results are mixed among different classifications of defects; VPO: velopharyngeal. 
Complications such as necrosis, ${ }^{8,29}$ partial loss of tissue, ${ }^{7,10}$ and oronasal fistulas, $,, 35,36$ which are associated with reconstructive operations, tend to be more serious than those associated with obturator prostheses, ${ }^{10}$ possibly because of the greater manipulation of tissue and longer operating time. No complications related to obturator prostheses were reported, which suggests that any damage was minor, and the problem could be corrected in the laboratory, avoiding the need for a second operation. Nevertheless, healing and postoperative modification of the bone could result in a poor fit, which could make the prosthesis uncomfortable and insecure, and the need for adaptation could involve a large number of medical appointments.

There was no consensus between the authors in relation to the presented theme, which is a limitation to this review. Some ${ }^{8,10}$ reported better results in patients who had tissue grafts and in those who had large or anterior defects, but others ${ }^{7,9}$ stated that obturator prostheses were more efficient when associated with reconstructive surgery. However, based on our findings, the treatment of choice will depend on each individual case, and the location and extent of the defect does not always correlate with the method of rehabilitation. According to Breeze et al ${ }^{14}$ the use of an obturator prosthesis, particularly if retained with implants, is a viable option. Another limitation that hampers comparison is the lack of a standard for the reporting of outcomes. If these were reported separately, for example, the extent of the defect, classification, or type of rehabilitation, the results could be compared more accurately.

In conclusion, before deciding on the best treatment, surgeons must consider the size of the defect and the extent of resection of the hard and soft palates (if included). They must also consider whether patients have had radiotherapy, the morbidity after resection, and the psychological effect of maxillectomy. $., 10,14$

\section{Conflict of interest}

We have no conflicts of interest.

\section{Ethics statement/confirmation of patients' permission}

None required.

\section{References}

1. Futran ND, Wadsworth JT, Villaret D, et al. Midface reconstruction with the fibula free flap. Arch Otolaryngol Head Neck Surg 2002;128:161-6.

2. Sun J, Shen Y, Li J, et al. Reconstruction of high maxillectomy defects with the fibula osteomyocutaneous flap in combination with titanium mesh or a zygomatic implant. Plast Reconstr Surg 2011;127:150-60.
3. Brickman DS, Reh DD, Schneider DS, et al. Airway management after maxillectomy with free flap reconstruction. Head Neck 2013;35:1061-5.

4. Clark JR, Vesely M, Gilbert R. Scapular angle osteomyogenous flap in postmaxillectomy reconstruction: defect, reconstruction, shoulder function, and harvest technique. Head Neck 2008;30:10-20.

5. Browne JD, Butler S, Rees C. Functional outcomes and suitability of the temporalis myofascial flap for palatal and maxillary reconstruction after oncologic resection. Laryngoscope 2011;121:1149-59.

6. Liu WW, Peng HW, Guo ZM, et al. Immediate reconstruction of maxillectomy defects using anterolateral thigh free flap in patients from a low resource region. Laryngoscope 2012;122:2396-401.

7. Bernhart BJ, Huryn JM, Disa J, et al. Hard palate resection, microvascular reconstruction, and prosthetic restoration: a 14-year retrospective analysis. Head Neck 2003;25:671-80.

8. Costa H, Zenha H, Sequeira H, et al. Microsurgical reconstruction of the maxilla: algorithm and concepts. J Plast Reconstr Aesthet Surg 2015;68:e89-104.

9. Elsherbiny M, Mebed A, Mebed H. Microvascular radial forearm fasciocutaneous free flap for palatomaxillary reconstruction following malignant tumor resection. J Egypt Natl Canc Inst 2008;20:90-7.

10. Moreno MA, Skoracki RJ, Hanna EY, et al. Microvascular free flap reconstruction versus palatal obturation for maxillectomy defects. Head Neck 2010;32:860-8.

11. Kwon HB, Chang SW, Lee SH. The effect of obturator bulb height on speech in maxillectomy patients. J Oral Rehabil 2011;38:185-95.

12. Moher D, Liberati A, Tetzlaff J, et al. Preferred reporting items for systematic reviews and meta-analyses: the PRISMA statement. Int J Surg 2010;8:336-41.

13. Higgins JP, Green S. Cochrane handbook for systematic reviews of interventions version 5.1.0. The Cochrane Collaboration, 2011. Available from URL: http://handbook.cochrane.org/ (last accessed 23 October 2017).

14. Breeze J, Rennie A, Morrison A, et al. Health-related quality of life after maxillectomy: obturator rehabilitation compared with flap reconstruction. Br J Oral Maxillofac Surg 2016;54:857-62.

15. Aramany MA. Basic principles of obturator design for partially edentulous patients. Part I: Classification. 1978 [classical article]. J Prosthet Dent 2001:86:559-61.

16. Cordeiro PG, Santamaria E. A classification system and algorithm for reconstruction of maxillectomy and midfacial defects. Plast Reconstr Surg 2000;105:2331-48.

17. Brown JS, Rogers SN, McNally DN, et al. A modified classification for the maxillectomy defect. Head Neck 2000;22:17-26.

18. Okay DJ, Genden E, Buchbinder D, et al. Prosthodontic guidelines for surgical reconstruction of the maxilla: a classification system of defects. $J$ Prosthet Dent 2001;86:352-63.

19. Cohen J. Weighted kappa: nominal scale agreement with provision for scaled disagreement or partial credit. Psychol Bull 1968;70:213-20.

20. Coleman K, Norris S, Weston A, et al. NHMRC additional levels of evidence and grades for recommendations for developers of guidelines. Stage 2 consultation early 2008 - end June 2009. Available from URL: www.nhmrc.gov.au/_files_nhmrc/file/guidelines/stage_2_consultation _levels_and_grades.pdf (last accessed 23 October 2017).

21. Sakuraba M, Kimata Y, Ota Y, et al. Simple maxillary reconstruction using free tissue transfer and prostheses. Plast Reconstr Surg 2003;111:594-600.

22. Rieger JM, Tang JA, Wolfaardt J, et al. Comparison of speech and aesthetic outcomes in patients with maxillary reconstruction versus maxillary obturators after maxillectomy. J Otolaryngol. Head Neck Surg 2011:40:40-7.

23. Wang F, Huang W, Zhang C, et al. Functional outcome and quality of life after a maxillectomy: a comparison between an implant supported obturator and implant supported fixed prostheses in a free vascularized flap. Clin Oral Implants Res 2017;28:137-43.

24. Spiro RH, Strong EW, Shah JP. Maxillectomy and its classification. Head Neck 1997;19:309-14. 
25. Baj A, Youssef DA, Monteverdi R, et al. Reconstruction of partial maxillary defects with the double-barrel fibula free flap. Acta Otorhinolaryngol Ital 2010;30:299-302.

26. Murphy J, Isaiah A, Wolf JS, et al. Quality of life factors and survival after total or extended maxillectomy for sinonasal malignancies. J Oral Maxillofac Surg 2015;73:759-63.

27. Jiang FF, Hou Y, Lu L, et al. Functional evaluation of a CAD/CAM prosthesis for immediate defect repair after total maxillectomy: a case series of 18 patients with maxillary sinus cancer. J Esthet Restor Dent 2015;27:S80-9.

28. Kumar VA, Hofstede TM, Ginsberg LE. CT imaging features of obturator prostheses in patients following palatectomy or maxillectomy. AJNR Am J Neuroradiol 2011;32:1926-9.

29. Baliarsing AS, Kumar VV, Malik NA, et al. Reconstruction of maxillectomy defects using deep circumflex iliac artery-based composite free flap. Oral Surg Oral Med Oral Pathol Oral Radiol Endod 2010;109:e8-13.

30. Zhang WB, Wang Y, Liu XJ, et al. Reconstruction of maxillary defects with free fibula flap assisted by computer techniques. J Craniomaxillofac Surg 2015;43:630-6.
31. Kumar P, Jain V, Thakar A, et al. Effect of varying bulb height on articulation and nasalance in maxillectomy patients with hollow bulb obturator. J Prosthodont Res 2013;57:200-5.

32. Hoshiai T, Iida T, Taniguchi H. Vibratory properties of maxillary dentition in maxillectomy patients wearing metal framework obturator prostheses with three different metal materials. J Prosthodont Res 2011;55:252-61.

33. Chigurupati R, Aloor N, Salas R, et al. Quality of life after maxillectomy and prosthetic obturator rehabilitation. J Oral Maxillofac Surg 2013;71:1471-8.

34. Depprich R, Naujoks C, Lind D, et al. Evaluation of the quality of life of patients with maxillofacial defects after prosthodontic therapy with obturator prostheses. Int J Oral Maxillofac Surg 2011;40:71-9.

35. Andrades P, Rosenthal EL, Carroll WR, et al. Zygomatic-maxillary buttress reconstruction of midface defects with the osteocutaneous radial forearm free flap. Head Neck 2008;30:1295-302.

36. Amin MA, Bailey BM, Swinson B, et al. Use of the buccal fat pad in the reconstruction and prosthetic rehabilitation of oncological maxillary defects. Br J Oral Maxillofac Surg 2005;43:148-54. 